\title{
Susceptibility of Some Common Container Weeds to Phytophthora ramorum
}

\author{
Nina Shishkoff, Research Plant Pathologist, ARS/USDA, Foreign Disease/Weed Science Research Unit. Frederick, MD 21702
}

\begin{abstract}
Shishkoff, N. 2012. Susceptibility of some common container weeds to Phytophthora ramorum. Plant Dis. 96:1026-1032.

Phytophthora ramorum is known to infect a number of ornamental plants grown in containerized culture. However, pots may also contain weeds. In this research, the foliage of 14 common weeds of containerized plant culture was inoculated with $P$. ramorum to determine susceptibility of aboveground parts. Three species were found to develop leaf lesions: northern willowherb (Epilobium ciliatum), fireweed (Chamerion angustifolium), and a fern (Pteris cretica). Weed roots from 11 species were inoculated to see if $P$. ramorum could persist on roots, and $P$. ramorum was isolated from most plant roots 1 month after

they were recovered only to a minor extent from surface-sterilized roots of weeds. Additional experiments were done to collect and sample runoff from pots containing inoculated plants to see if inoculum was produced on weed roots. In these experiments, little inoculum was found in runoff from root-inoculated weeds compared to Viburnum tinus. Percent root colonization recorded from washed roots was significantly greater in Viburnum compared to the weeds, and weeds that were foliar hosts had greater root colonization than weeds that were not.
\end{abstract} inoculation when the washed roots were plated on selective medium;
Phytophthora ramorum Werres, De Cock \& Man in't Veld, the cause of sudden oak death on the West Coast, is known to infect a number of ornamental plants grown in containerized culture, such as Rhododendron, Camellia, Viburnum, and Syringa $(10,40)$. By the end of 2004, infected ornamentals were inadvertently shipped from California to at least 40 states (38), leading to the instigation of an Emergency Federal Order, which placed restrictions on the movement of host plants shipped out of California, Oregon, and Washington (1). Nurseries that grow regulated plants in regulated areas must be inspected and found disease-free before they can ship regulated plants to other states. The Federal Order requires that sampling "focus on, but not be limited to, regulated articles of nursery stock". This has been interpreted to mean that not only should known hosts be sampled, but also any plants suspected of being hosts and nursery stock not known to be a host but showing foliar symptoms of Phytophthora.

However, nurseries may also contain weeds, and the role of containerized weeds in the $P$. ramorum disease cycle is unknown. Weeds are known to serve as reservoirs for insects that attack a given crop $(3,6)$, but they can also serve as reservoirs for bacteria (5), viruses $(6,17)$, nematodes $(4,6,37)$, and fungi $(24,41,42)$. For some pathogenic fungi, weeds have been shown to serve as "symptomless carriers" $(2,7,23,33)$. With oomycetes, the importance of weed reservoirs depends on the pathogen. A Pythium species causing disease on cowpea was shown to be harbored by the weed Physalis angulata in Nigeria (20); however, Pythium is a good saprophyte and could probably be found in the soil and plant debris and associated with the roots of many weeds. In the case of Bremia lactucae, an obligate parasite, the discovery that it is harbored by Sonchus weeds was significant with regard to lettuce crops (39). Phytophthora falls between the extremes of Pythium and Bremia: it is a poor saprophyte and tends to exist in soil as oospores or chlamydospores, or for shorter periods of time in undecomposed plant tissue. In the case of Phytophthora infestans, when both mating

Corresponding author: Nina Shishkoff,

E-mail: Nina.Shishkoff@ars.usda.gov

Accepted for publication 10 February 2012

http://dx.doi.org/10.1094/PDIS-09-10-0695-RE

This article is in the public domain and not copyrightable. It may be freely reprinted with customary crediting of the source. The American Phytopathological Society, 2012. types are present, the pathogen can persist in soil in the form of oospores, but when only one mating type is present it persists as mycelium in cull piles of potato tubers and has also been found on the roots of 47 Solanum species (12). In Florida cucurbit fields, Phytophthora capsici was found associated with the roots of several weeds, including Portulaca oleracea and Solanum americanum $(14,26)$. In pathogenicity tests, only the weed Solanum nigrum was killed by the pathogen; other weed species showed various degrees of root colonization without mortality (14) and could serve as a means of survival for the pathogen over fallow periods.

In this research, the foliage of common weeds in containerized plant culture was inoculated with $P$. ramorum to determine susceptibility of aboveground parts. Plants considered to be common weeds of containerized plants were chosen, as well as some plants that were probable foliar hosts and common weeds in our own facility (Pteris cretica and Epilobium ciliatum). The roots were inoculated in separate experiments to see if the pathogen could persist on washed roots or within surface-sterilized roots of these plants. Additional experiments were done on the roots of selected weed hosts (some foliar hosts, some asymptomatic in inoculation tests of foliage) to collect and sample runoff from pots containing inoculated plants to see if inoculum was produced on inoculated weed roots.

\section{Materials and Methods}

Plant propagation. Fourteen weed taxa that were considered common in container culture or suspected of being hosts were tested for susceptibility to P. ramorum (Table 1). Weeds were grown from seeds planted in Turface MVP (a calcined, montmorillonite clay substrate medium manufactured by Profile Products LLC, Buffalo Grove, IL) in 24-insert trays, except for liverwort (Marchantia polymorpha), fern (Pteris cretica), and moss (Funaria hygrometrica), which were collected as thalli or protonemata and transplanted onto Turface. Turface is a soil substrate useful for studying belowground interactions of roots and microorganisms because of its good cultural properties (good water retention with good air circulation) plus the ease with which roots can be washed free of it $(8,25)$. Weed hosts were grown for 5 to 8 weeks before use. Positive controls for pathogenicity tests were rooted cuttings of Camellia sinensis, Rhododendron 'Cunningham's White', Syringa vulgaris, Viburnum $\times$ pragense 'Decker', V. tinus 'Spring Bouquet', or V. davidii.

Isolate. All work was conducted in containment under APHIS permit for P. ramorum. The pathogen isolate (NS-5C) used in these 
experiments was originally recovered from Camellia sasanqua 'Bonanza' in California in 2003. It contained the same single nucleotide polymorphism profile as known isolates of U.S. clonal lineage NA1 typically found in California forests and nurseries $(15,16)$. This isolate caused disease on a wide array of plants $(27,20,31)$. It was maintained in sterile water culture or on pimaricin-ampicillin-rifampicin-PCNB-Hymexazol $\left(\mathrm{P}_{5} \mathrm{ARPH}\right)$ agar selective medium $(18,34)$ and inoculated onto and reisolated from Rhododendron or Camellia every 6 months to maintain pathogenicity. The culture is also maintained in liquid nitrogen as part of the international collection of plant pathogens at the National Cancer Institute's Central Repository in Frederick, MD.

Aboveground inoculation. This examination of weed species for foliar infection was meant as a preliminary screening so that weed species of interest could be selected for further study. The goal of the experiment was simply to identify foliar hosts among common weeds. Weed species were inoculated at 6 to 8 weeks after planting on aboveground parts to determine if any common container weed was a foliar host of $P$. ramorum. Sporangia in suspension were prepared as described previously (36), by placing mycelial plugs from colonies grown on V8 agar into a sterile $1 \%$ soil extract solution for $48 \mathrm{~h}$. Plants were inoculated by inverting foliage and branch tips into the sporangial suspension $\left(3 \times 10^{3}\right.$ sporangia $\mathrm{ml}^{-1}$ ) and using a paintbrush to apply the suspension to any aboveground part of the plant missed by immersion. The plants were inoculated in batches ( 20 to 30 plants; essentially the number of plants that could easily fit in one dew chamber), with individuals of each tested species inoculated as part of at least two batches. Each batch included 1-3 rooted cuttings of $R$. 'Cunningham's White' or $S$. vulgaris used as positive controls. Overall, this meant that plants were inoculated in 23 batches over the course of 2 years. Each batch of inoculated plants was placed in a dew chamber at $20^{\circ} \mathrm{C}$ for 4 days. Diseased plants and diseased leaves per plant were recorded, and each diseased leaf was rated for percent disease area. From these, one could measure disease as the number of infected plants per total inoculated, the number of infected leaves per total leaves on the plant, and the amount of infected tissue averaged over the total number of leaves on the plant. Because statistical analysis of plants run in so many batches is problematic, even with the presence of a positive control, none was attempted. Because of the hydrophobic character of Oxalis leaves, additional tests were run to see if wounded Oxalis leaves would develop symptoms. Three plants each of Oxalis corniculata, $P$. cretica, and V. tinus were inoculated with a zoospore suspension (zoospores produced by placing sporangial suspensions at $4{ }^{\circ} \mathrm{C}$ for half an hour and then warming them to room temperature, causing the release of zoospores, then diluting to $3.5-4 \times 10^{4}$ zoospores $\mathrm{ml}^{-1}$ ). Four leaves on each plant were wounded by poking a dissecting needle into leaf tissue on each side of the midrib of each leaf. Each wound was covered with a small piece of tissue paper and then inoculated with the zoospore suspension, the tissue paper holding the suspension at the wound site rather than (in the case of $O$. corniculata) beading up and falling off the plant. One plant of each species was wounded and then treated with sterile distilled water to serve as a control. Plants were incubated in a dew chamber at $20^{\circ} \mathrm{C}$ for 5 days; then the wounded leaves were examined for the presence of lesions and the lesion tissue was surface-sterilized in $0.06 \%$ bleach for $1 \mathrm{~min}$ and plated on PARPH to detect the presence of the pathogen. The experiment was repeated once.

Root inoculation. This examination of weed species for root infection was meant as a preliminary screening so that weed species of interest could be selected for further study. In the work below (inoculum production from roots), a smaller number of weed species were studied in greater depth. Roots of 12 weed species (listed in Table 2) were inoculated by pouring $15 \mathrm{ml}$ of a sporangial suspension (approximately 3,000 sporangia $\mathrm{ml}^{-1}$ ) of $P$. ramorum over the roots of the test plants established in Turface (Table 2). Plants were inoculated as part of batches (20 to 30 plants), and each species was inoculated as part of at least two batches, for a total of 12 batches, with $V$. davidii, $V . \times$ pragense 'Decker', $C$. sinensis, or $S$. vulgaris serving as a positive control and one plant per species in each batch treated with distilled water and serving as a negative control. As part of some batches, pots of Turface alone were treated with a sporangial suspension or water alone. Plants were incubated under greenhouse conditions for a month, then root segments (or granules of Turface) were either washed and directly plated onto selective PARPH medium, or surface-sterilized in $0.06 \%$ sodium hypochlorite for $5 \mathrm{~min}$ before plating. Because statistical analysis of plants run in so many batches is problematic, even with the presence of a positive control, none was attempted.

Inoculum production from roots. Selected weed species were tested for inoculum production on roots using an assay developed to quantify $P$. ramorum inoculum in runoff (32). Some species were selected because they had been determined to be foliar hosts, others because of relatively high root colonization, and others because of relatively low root colonization. The experiment was de-

Table 1. Susceptibility of weed species inoculated on aboveground parts with Phytophthora ramorum and evaluated for foliar symptoms, with Rhododendron 'Cunningham's White' or Syringa vulgaris serving as positive controls

\begin{tabular}{|c|c|c|c|c|}
\hline Plant name & \# Plants inoculated ${ }^{x}$ & $\%$ Infected plants & $\%$ Infected leaves & $\begin{array}{c}\% \text { Lesion area } \\
\text { on infected leaves }\end{array}$ \\
\hline \multicolumn{5}{|l|}{ Test plants } \\
\hline Groundsel (Senecio vulgaris L.) & 33 & 0 & 0 & - \\
\hline Marsh yellowcress (Rorippa islandica (Oeder) Borb) & 41 & 0 & 0 & - \\
\hline Bittercress (Cardamine hirsuta L.) & 26 & 0 & 0 & - \\
\hline Liverwort $(\text { Marchantia polymorpha } \mathrm{L} .)^{\mathrm{z}}$ & 9 & 0 & 0 & - \\
\hline Prostrate spurge (Chamaesyce maculata (L.) Small) & 19 & 0 & 0 & - \\
\hline Pearlwort (Sagina procumbens L.) & 14 & 0 & 0 & - \\
\hline Northern willowherb (Epilobium ciliatum Raf.) & 43 & 55.8 & 11.8 & $11.2 \pm 19.0$ \\
\hline Fireweed (Chamerion angustifolium (L.) Holub.) & 25 & 76.0 & 21.8 & $7.3 \pm 9.7$ \\
\hline Common chickweed (Stellaria media (L.) Vill.) & 43 & 0 & 0 & - \\
\hline Creeping woodsorrel (Oxalis corniculata L.) & 22 & 0 & 0 & - \\
\hline Purselane (Portulaca oleracea L.) & 40 & 0 & 0 & - \\
\hline Groundsel tree (Baccharis halimifolia) & 19 & 0 & 0 & - \\
\hline Moss $(\text { Funaria hygrometrica Hedw. })^{\mathrm{z}}$ & 12 & 0 & 0 & - \\
\hline Fern (Pteris cretica L.) & 35 & 31.0 & 6.4 & $2.0 \pm 4.2$ \\
\hline \multicolumn{5}{|l|}{ Known foliar hosts } \\
\hline Rhododendron 'Cunningham's White' & 48 & 95.0 & 45.0 & $15.8 \pm 15.3$ \\
\hline Syringa vulgaris $\mathrm{L}$. & 21 & 100.0 & 44.6 & $22.3 \pm 18.8$ \\
\hline
\end{tabular}


signed to allow quantitative comparison of the plants. In one experiment, four plants each of $O$. corniculata, Sagina procumbens, Cardomine hirsuta, E. ciliatum, and V. tinus were inoculated by pouring $15 \mathrm{ml}$ of a sporangial suspension (500 sporangia ml $\mathrm{m}^{-1}$ ) over each root system established in approximately $80 \mathrm{ml}$ of Turface and allowing $24 \mathrm{~h}$ for infection. Plants were then removed from the infested Turface and the roots carefully washed to remove all Turface granules and residual inoculum. They were first immersed in a beaker of distilled water and agitated to remove most of the Turface, then rinsed under a running stream of water. The cuttings were then transplanted into $50 \times 20 \mathrm{~mm}$ plastic pots containing approximately $100 \mathrm{ml}$ of clean Turface. The bottom of each pot was lined with plastic mesh (mesh size number 53) for easy drainage. After inoculation, plants were kept in a controlledenvironment chamber set at $20^{\circ} \mathrm{C}$ with a 14-h photoperiod. Each treatment had its own plastic tray so that runoff from one treatment did not have an opportunity to contact plants from another treatment. Trays from a given experiment were placed in the same growth chamber, but were moved randomly to different positions within the growth chamber at each sampling time. Runoff was sampled at 1, 4, 7, 10, 13, and 16 days after inoculation. Sampling consisted of pouring enough distilled water through the pot to collect 15 to $20 \mathrm{ml}$ of runoff into a plastic centrifuge tube. Runoff was subsampled using a plastic syringe to add 1-ml aliquots to each of three plates of PARPH. Plates were swirled to distribute a film of runoff over the entire surface, and then incubated at $20^{\circ} \mathrm{C}$. Plates were examined weekly for 3 weeks and all colonies counted using a dissecting microscope with dark-field illumination (under which colonies of $P$. ramorum are characteristically highly refractive) in order to quantify the colony-forming units per milliliter of runoff. At the end of the experiment, roots were washed before plating or surface-sterilized for $5 \mathrm{~min}$ in $0.025 \%$ sodium hypochlorite, rinsed, and left to sit in distilled water for $30 \mathrm{~min}$, and then $1-\mathrm{cm}$ segments plated on PARPH selective medium; the remainder of the root system was dried at $100^{\circ} \mathrm{C}$. Ideally, 60 segments from washed roots and 60 from surface-sterilized roots were plated; less if the root system was smaller. After a 1 -week incubation at $20^{\circ} \mathrm{C}$, colonies from plated roots were counted to determine percent infection, and the roots segments were collected and dried at $100^{\circ} \mathrm{C}$. The dry weight of the entire root system for each plant was recorded. When inoculum over the test period was added up for each plant, total inoculum could be divided by root weight to calculate colonyforming units per gram of dry root weight. The experiment was conducted three times.

A second experiment looked at inoculum in runoff from $P$. cretica, Senecio vulgaris, and V. tinus. Samples of runoff were taken at 1, 4, 7, 10, and 13 days after inoculation, and the experiment was run four times.

For two weed species, additional experiments were run where runoff was assayed over a longer time period. Four plants of $O$. corniculata and four of $V$. tinus were inoculated as described above; two plants of each species were treated with water alone to serve as negative controls. Samples of runoff were taken at 7, 14, 21 , and 28 days. Roots were sampled as described previously. The experiment was run three times. The experiment was run three more times using $P$. oleracea instead of $O$. corniculata.

Statistical analysis. Inoculum in runoff over time was analyzed statistically after "colonies per pot" was transformed using a logarithmic (base e) transformation with " 0 " values replaced by "1" to retain low counts on the log scale. The transformed variable was analyzed by random coefficient analysis using the mixed model analysis of covariance program in SAS (PROC MIXED; SAS Institute, Cary, NC) to take into account that the same plants were sampled over time. The terms in the random statements (expt and day) were used as random in the random coefficient analysis, while the test variable was considered fixed. Pairwise treatment differences were compared using the least significant difference (LSD) at each sampling time. The amount of inoculum produced by each plant could be totaled for the entire experimental time period and divided by dry root weight to get "colonies per gram dry root weight" for each plant. This was analyzed by general linear models (GLM) in SAS and treatment means compared using LSD to test the treatment differences. Percent root colonization at the end of the experiment was analyzed by doing an arcsine square root transformation and comparing treatments using GLM and a Dunnett test specifying $V$. tinus as the positive control. A logistic regression was

Table 2. Susceptibility of weed species inoculated on belowground parts with Phytophthora ramorum and evaluated for root infection, with Camellia sinensis, Syringa vulgaris, Viburnum davidii, or $V . \times$ pragense 'Decker' serving as positive controls

\begin{tabular}{|c|c|c|c|c|c|}
\hline \multirow[b]{2}{*}{ Inoculated plant } & \multirow[b]{2}{*}{ Foliar host } & \multirow[b]{2}{*}{ \# Inoc ${ }^{y}$} & \multicolumn{3}{|c|}{ Percent infection } \\
\hline & & & $\begin{array}{l}\% \text { Infected } \\
\text { plants }\end{array}$ & $\begin{array}{c}\% \text { Washed roots } \\
\text { infected }\end{array}$ & $\begin{array}{l}\% \text { Surface-sterilized } \\
\text { roots infected }\end{array}$ \\
\hline \multicolumn{6}{|l|}{ Test plants } \\
\hline Groundsel (Senecio vulgaris) & No & 21 & 28.6 & 3.4 & 0.2 \\
\hline Marsh yellowcress (Rorippa islandica) & No & 27 & 29.6 & 7.3 & 0.0 \\
\hline Bittercress (Cardamine hirsuta) & No & 12 & 9.1 & 2.1 & 0.0 \\
\hline Prostrate spurge (Chamaesyce maculata) & No & 23 & 0.0 & 0.0 & 0.0 \\
\hline Pearlwort (Sagina procumbens) & No & 21 & 9.5 & 0.5 & 0.0 \\
\hline Northern willowherb (Epilobium ciliatum) & Yes & 20 & 57.9 & 10.2 & 0.5 \\
\hline Fireweed (Chamerion angustifolium) & Yes & 24 & 100.0 & 18.8 & 3.0 \\
\hline Common chickweed (Stellaria media) & No & 30 & 20.0 & 1.2 & 0.1 \\
\hline Creeping woodsorrel (Oxalis corniculata) & No & 15 & 26.7 & 10.0 & 0.3 \\
\hline Purselane (Portulaca oleracea) & No & 34 & 26.0 & 18.4 & 0.4 \\
\hline Groundsel tree (Baccharis halimifolia) & No & 14 & 57.1 & 3.2 & 0.0 \\
\hline Fern (Pteris cretica) & Yes & 10 & 0.0 & 0.0 & 0.0 \\
\hline \multicolumn{6}{|l|}{ Known root hosts } \\
\hline Camellia sinensis & Yes & 8 & 87.5 & 15.0 & 6.0 \\
\hline Syringa vulgaris & Yes & 16 & 56.2 & 13.4 & 7.1 \\
\hline Viburnum davidii & Yes & 15 & 66.7 & 7.8 & 2.4 \\
\hline Viburnum $\times$ pragense 'Decker' & Yes & 22 & 91.0 & 22.0 & 17.0 \\
\hline Inoculated planting medium & & \# Pots inoc & $\begin{array}{l}\% \text { Pots } \\
\text { infected }\end{array}$ & $\begin{array}{c}\% \text { Washed } \\
\text { granules infected }\end{array}$ & $\begin{array}{l}\text { \% Surface-sterilized } \\
\text { granules infected }\end{array}$ \\
\hline Turface $^{\mathrm{z}}$ & - & 16 & 25.0 & 0.5 & 0.0 \\
\hline
\end{tabular}


also conducted with comparisons among species done using the odds ratio and Proc GLIMMIX.

\section{Results}

Aboveground inoculation. Of weeds tested, only E. ciliatum, C. angustifolium, and P. cretica showed foliar symptoms (Table 1). Symptoms and levels of infection were comparable to those observed in similar inoculation experiments of known foliar hosts (Fig. 1), and the pathogen could be recovered from such lesions if plant tissue was surface-sterilized for $1 \mathrm{~min}$ in $0.06 \%$ sodium hypochlorite and then placed on selective medium. In experiments where wounded leaves were inoculated, the wound site on $V$. tinus and $P$. creticas leaves frequently developed a subtending brown lesion noticeably larger than the slight browning of the wound edge on control plants, and the pathogen commonly could be recovered from the surface-sterilized wound site (75\% of wounds for $V$. tinus, and $77 \%$ for $P$. cretica). Wounded-inoculated $O$. corniculata leaves did not show any browning at the wound site that differed from that found on wounded uninoculated controls; on one occasion the pathogen was recovered from a surface-sterilized wound site on an inoculated plant $(2 \%$, which was one wound site on one plant in the second trial). O. corniculata was therefore not considered to be a foliar host.

Infection of roots. When root infection was examined, the results were less clear-cut (Table 2). The positive controls showed root infection even when roots were surface-sterilized for $5 \mathrm{~min}$ ( 7.8 to $22 \%$ for washed roots; 2.4 to $17 \%$ for surface-sterilized roots), suggesting internal colonization. In the case of the weeds shown to be foliar hosts, the pathogen could be recovered from the roots of E. ciliatum and $C$. angustifolium (both washed and surface-sterilized) but not from those of $P$. cretica (however, see "production of inoculum from infected roots", below). In weeds that were not shown to be foliar hosts, low levels of pathogen recovery were seen. The pathogen was recovered less frequently, whether measured as "\% plants infection" or "\% root infection", and while it could be recovered from washed roots, it was rarely recovered from surface-sterilized roots. No colonies resembling $P$. ramorum were isolated from control roots. Low levels of inoculum were recovered from inoculated Turface that was washed and plated on PARPH ( $0.5 \%$ of plated granules), and none was recovered from surface-sterilized granules.

Production of inoculum from infected roots. Compared to $V$. tinus, little inoculum was found in runoff from root-inoculated weeds (Figs. 2A and B and 3A). In the first experiment, where $V$. tinus was compared with E. ciliatum, O. corniculata, $C$. hirsuta, and $S$. procumbens, log-transformed CFU over time fit an exponential regression model (fixed effects day, day-weed, and day-dayweed were all significant at $P<0.05$; day-day was significant at $P$ $<0.06$ ) (Fig 2B). Differences of least squares means for each day showed that, beginning on day $4, V$. tinus gave off significantly

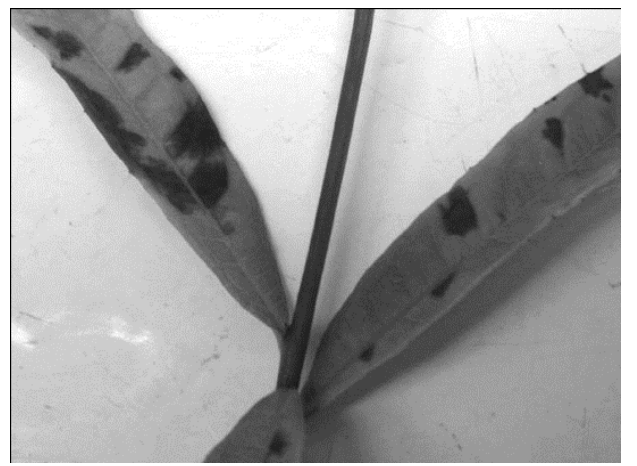

Fig. 1. Chamerion Angustifolium showing foliar symptoms of infection by Phytophthora ramorum. Weed species were inoculated at 6 to 8 weeks after planting on aboveground parts with a sporangial suspension $\left(3 \times 10^{3}\right.$ sporangia $\left.\mathrm{ml}^{-1}\right)$ along with positive controls (Rhododendron 'Cunningham's White' or Syringa vulgaris). Inoculated plants were then placed in a dew chamber at $20^{\circ} \mathrm{C}$ for 4 days. more inoculum than the weeds (Fig. 2A and B). When total inoculum produced over the course of the experiment (measured as CFU/dry root weight) was analyzed, data could not be normalized until counts from $S$. procumbens (the species with the lowest counts and therefore the most zero counts) were excluded. In a comparison of the remaining species, inoculum was strongly influenced by plant species $(P<0.0001)$ with paired $t$ tests showing significantly more inoculum produced by $V$. tinus than by the three weeds. Using GLM to compare percent root colonization among species (after an arcsine square root transformation), species were found to have significant differences in colonization $(P<0.0001)$, and Dunnett's $t$ test comparing the three weeds to $V$. tinus showed them to differ significantly from it. A logistic model was also significant $(P<0.0001)$, with odds ratio estimates demonstrating that all four weeds differed from Viburnum. According to this test, Viburnum was 8.1 times as likely to get infected as E. ciliatum and 66 to 500 times as likely to become infected as the rest of the weed species. Using the GLIMMIX procedure, a least squares mean test
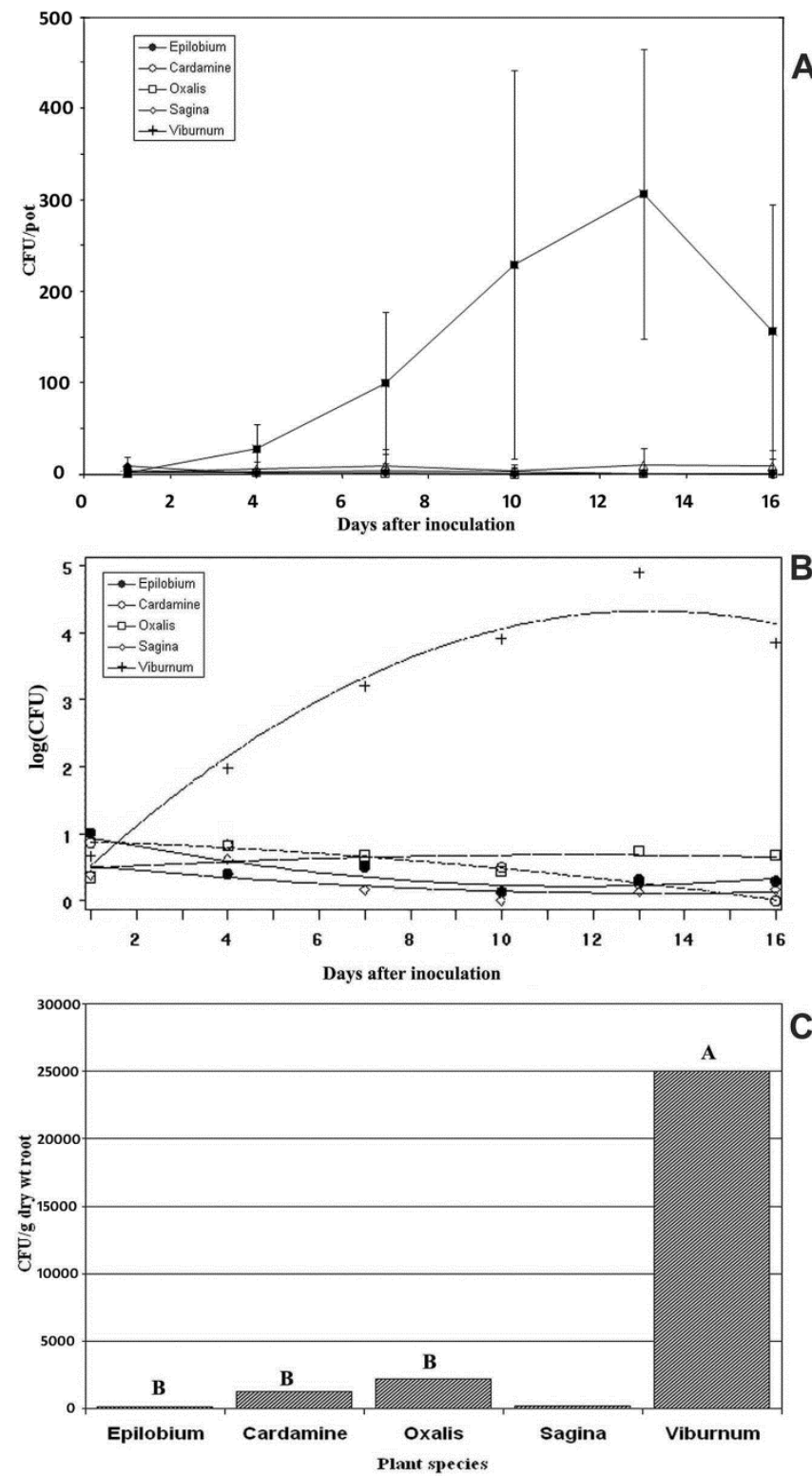

Fig. 2. Amount of inoculum found in runoff from pots containing root-inoculated plants of Cardamine hirsute, Sagina procumbents, Epilobium ciliatum, Oxalis corniculata, and Viburnum tinus. A, Colony-forming units (CFU) in runoff per pot over time. Error bars denote $95 \%$ confidence interval. B, Regression lines from logtransformed data. C, Total inoculum in runoff for each species shown as CFU per gram dry root weight. Different letters over bars indicate that inoculum differed significantly between treatments according to a GLM analysis with paired $t$ tests. 

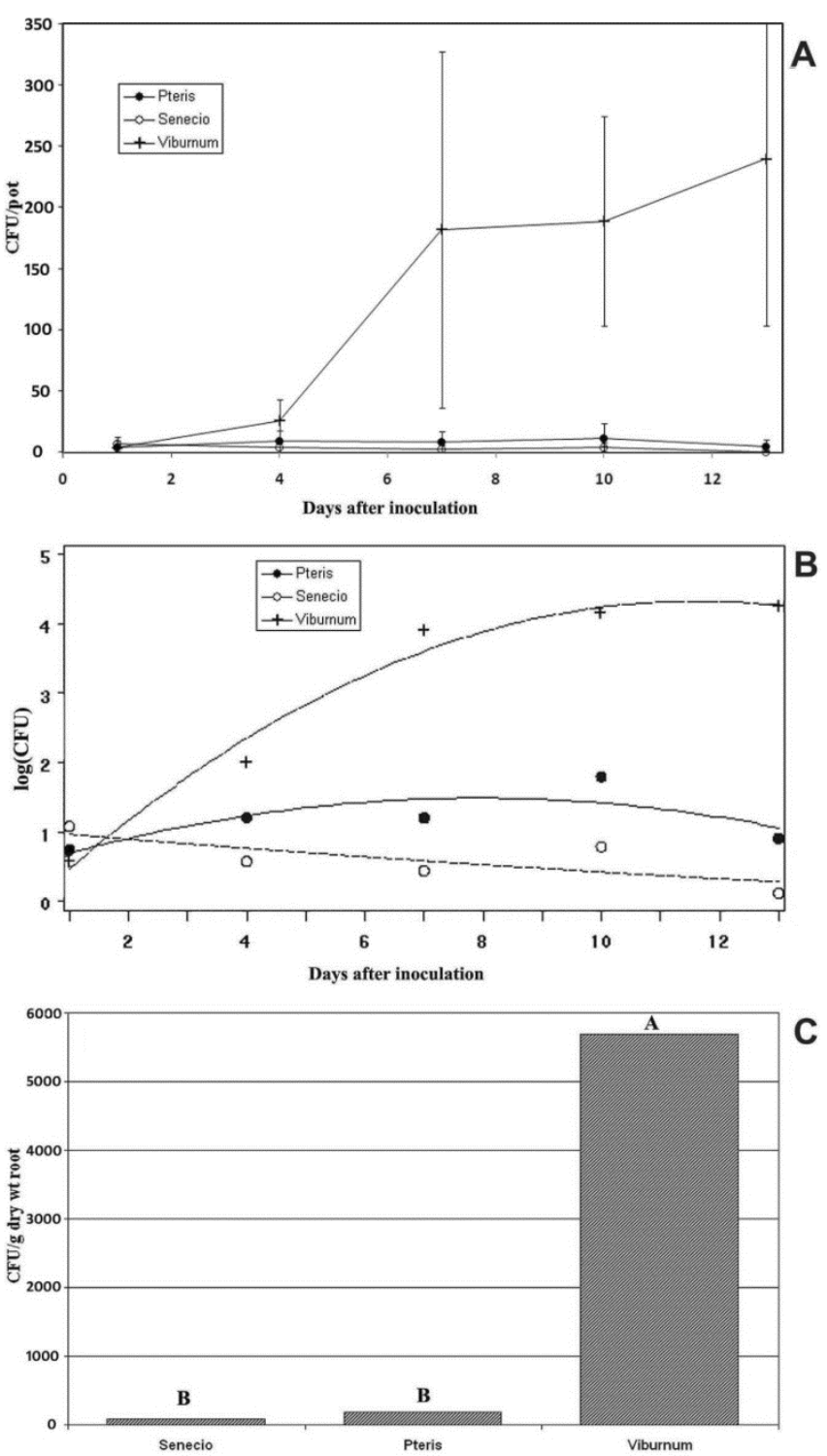

Fig. 3. Amount of inoculum found in runoff from pots containing root-inoculated plants of Senecio vulgaris, Pteris cretica, and Viburnum tinus. A, Colony-forming units (CFU) per pot over time. Error bars denote $95 \%$ confidence interval. B, Regression lines from log-transformed data. C, Total inoculum in runoff for each species shown as CFU per gram dry root weight. Different letters over bars indicate that inoculum differed significantly between treatments according to a GLM analysis with paired $t$ tests.

showed that Viburnum differed from all three weeds, and E. ciliatum (a foliar host) had significantly more infected roots than $O$. corniculata, C. hirsuta, or S. procumbens (Table 3). No inoculum was recovered from runoff from control plants and no infection was seen in control roots.

In the second experiment, where $V$. tinus was compared with $P$. cretica and Senecio vulgaris, log-transformed CFU over time fit an exponential regression model (fixed effects day, day-day, dayweed, and day-day-weed were all significant at $P<0.05$; weed was significant at $P<0.07$ ) (Fig. 3A). Differences of least square means for each day showed that, beginning on day $4, V$. tinus gave off significantly more inoculum than the weeds, and on days 7 and 10, $P$. cretica gave off significantly more inoculum than $S$. vulgaris. The linear coefficient of the regression equation was significantly different for each species, and the quadratic coefficients of $S$. vulgaris and $V$. tinus differed. When total inoculum (as CFU/dry root weight) was compared, inoculum was strongly influenced by plant species $(P<0.0001)$, with paired $t$ tests showing significantly more inoculum produced by Viburnum than by the two weeds. Using
GLM to compare percent colonization of roots among species, the model was significant $(P<0.0001$ for treatment), and Dunnett's $t$ test comparing $P$. cretica or $S$. vulgaris to $V$. tinus showed both to differ significantly. A logistic model was also significant $(P<$ 0.0001 ), with odds ratio estimates demonstrating that both weeds differed from $V$. tinus. According to this test, $V$. tinus was 90 times as likely to get infected as $P$. cretica and 200 times as likely to become infected as $S$. vulgaris. Using the GLIMMIX procedure, a least square means test showed that Viburnum differed from both weeds, and P. cretica (a foliar host) had greater root infection than $S$. vulgaris (Table 3). No inoculum was recovered from runoff from control plants and no infection was seen in control roots.

In longer experiments comparing runoff from $P$. oleracea to $V$. tinus over 28 days, at each sampling period $(7,14,21$, and 28 days), $V$. tinus gave off significantly more inoculum than $P$. oleracea $(P<0.0006)$. When total colonies recovered over the test period were corrected for dry root weight, $V$. tinus gave off significantly more colonies than $P$. oleracea $(P<0.0006)$, with $V$. tinus giving off $13,966 \mathrm{CFU} / \mathrm{g}$ dry root weight, while $P$. oleracea gave off $852 \mathrm{CFU} / \mathrm{g}$ dry root weight. Percent root infection for washed roots was significantly greater for $V$. tinus at the end of the experiment $(P<0.0001)$, with $V$. tinus infected at $36.1 \%$ and $P$. oleracea at $0.9 \%$. In tests comparing $O$. corniculata to $V$. tinus, the latter gave off significantly more inoculum at each sampling period $(P<$ $0.0006)$. When total colonies recovered over the test period were corrected for dry root weight, $V$. tinus gave off significantly more inoculum $(P=0.001)$ with an average of $6,430 \mathrm{CFU} / \mathrm{g}$ dry root weight, while $O$. corniculata gave off $51.3 \mathrm{CFU} / \mathrm{g}$ dry root weight. Percent root infection at the end of the experiment was significantly greater for $V$. tinus $(P<0.0001)$ at $24.8 \%$ and $O$. corniculata at $0.6 \%$.

\section{Discussion}

Three species of weeds were found to be foliar hosts of $P$. $r a$ morum, $P$. cretica, and two members of the Onagraceae $(C$. angustifolium and E. ciliatum). Of these, only E. ciliatum is considered to be one of the common weeds of container nurseries (19). Nonetheless, it suggests that weeds should be considered when nurseries are inspected for symptoms of $P$. ramorum blight.

The weeds that were foliar hosts of $P$. ramorum also showed some degree of root infection. The ability of roots of foliar hosts to become infected has been shown with various foliar hosts $(21,22,27-29,32,35)$, and in previous work, when the roots of known foliar hosts (such as V. tinus, Camellia spp., and S. vulgaris) were inoculated, the pathogen could be recovered from surfacesterilized roots, suggesting that roots were to some extent internally colonized (27-29). The work of Parke and Lewis (22) has shown that $P$. ramorum can spread in the vascular system of Rhododendron; such infections would likely be detected in surfacesterilized segments of root. In the present study, the pathogen could be recovered from the washed roots of weeds that were not foliar hosts although to a degree significantly less than found in foliar hosts. The pathogen was rarely isolated from surface-sterilized weed roots, suggesting that such colonization was largely superficial. Asymptomatic infection of plant roots is known for Phytophthora capsici on the roots of purselane and nightshade (14).

Although a small amount of inoculum (presumably in the form of sporangia or zoospores) was detected in runoff from colonized weed roots, none of the weeds tested, including the foliar hosts, produced as much inoculum as infected $V$. tinus. $V$. tinus roots have been seen to produce, in addition to sporangia, chlamydospores that are formed within infected tissue (N. Shishkoff, unpublished data), and chlamydospores can survive for long periods of time in soil or potting mix $(13,28)$. If transient infection of weed roots leads to chlamydospore production, this might be more significant than sporangia production. Phytophthora species are poor saprophytes, but they have been found in the potting mix of containerized plants showing no symptoms $(9,11)$. A pathogen associated with asymptomatic plants with colonized roots or present in infested soil would be unlikely to be detected until environmental 
Table 3. Percent infection of roots at the conclusion of an experiment to measure the amount of inoculum in runoff

\begin{tabular}{|c|c|c|c|c|c|c|c|}
\hline \multirow[b]{2}{*}{ Set $^{y}$} & \multirow[b]{2}{*}{ Inoculated plant } & \multirow[b]{2}{*}{$\begin{array}{c}\text { Foliar } \\
\text { symptoms }\end{array}$} & \multirow[b]{2}{*}{ \# Inoc } & \multicolumn{3}{|c|}{ Percent infection } & \multirow[b]{2}{*}{$\begin{array}{c}\text { Dry root } \\
\text { wt (g) }\end{array}$} \\
\hline & & & & $\begin{array}{c}\text { Plants } \\
\text { infected }\end{array}$ & $\begin{array}{l}\text { Washed } \\
\text { roots }^{z}\end{array}$ & $\begin{array}{l}\text { Sterilized } \\
\text { roots }\end{array}$ & \\
\hline \multirow[t]{5}{*}{1} & Bittercress (Cardamine hirsuta) & No & 12 & 33.3 & $1.7 \mathrm{~b}$ & 0.0 & 0.035 \\
\hline & Pearlwort (Sagina procumbens) & No & 12 & 16.7 & $0.5 \mathrm{a}$ & 0.0 & 0.071 \\
\hline & Northern willowherb (Epilobium ciliatum) & Yes & 12 & 58.3 & $14.3 \mathrm{c}$ & 0.8 & 0.192 \\
\hline & Creeping woodsorrel (Oxalis corniculata) & No & 12 & 33.3 & $2.2 \mathrm{~b}$ & 0.3 & 0.083 \\
\hline & Viburnum tinus & Yes & 12 & 100.0 & $57.5 \mathrm{~d}$ & 38.2 & 0.227 \\
\hline \multirow[t]{3}{*}{2} & Groundsel (Senecio vulgaris) & No & 16 & 12.5 & $1.2 \mathrm{a}$ & 0.0 & 0.061 \\
\hline & Fern (Pteris cretica) & Yes & 16 & 43.8 & $2.7 \mathrm{~b}$ & 0.0 & 0.077 \\
\hline & Viburnum tinus & Yes & 16 & 100.0 & $68.1 \mathrm{c}$ & 57.2 & 0.043 \\
\hline
\end{tabular}

y Set 1 shows the results of three experiments where 4 plants of each plant species was inoculated with $P$. ramorum; plant roots were sampled after 18 days and were plated on the selective medium after being washed or surface-sterilized in $0.025 \%$ sodium hypochlorite. Set 2 shows the results of four experiments where four plants of each plant was inoculated with $P$. ramorum; plant roots were sampled after 14 days. In all experiments, a fifth plant of each species was inoculated with distilled water and served as a negative control (not shown).

${ }^{\mathrm{z}}$ For each set of experiments, a percentage followed by a different letter indicates that the amount of root infection differed significantly in a logistic regression analysis using Proc GLIMMIX to make comparisons among species.

conditions allowed symptom development on aboveground plant parts. Tjosvold et al. (35) observed that buried infected leaf pieces could lead to foliar infection of lower leaves in Rhododendron, given abundant rainfall.

It is difficult to analyze the risk posed by weeds in containerized systems, but given that an infected lilac leaf fallen onto a pot surface can produce $960 \mathrm{CFU} /$ square inch (30), which is equivalent to $13,333 \mathrm{CFU} / \mathrm{g}$ dry weight leaf tissue, and an infected Viburnum root system can give off as many as $25,000 \mathrm{CFU} / \mathrm{g}$ dry weight over a 16-day period (result from the runoff experiment comparing $V$. tinus to E. ciliatum, $S$. procumbens, $C$. hirsuta, and $O$. corniculata, above), the risk of a root-colonized weed would seem to be less than the risk of poor sanitation or root infection of the susceptible ornamental plant itself. It would seem safe to suggest that any process that puts inoculum of $P$. ramorum into soil, whether from fallen leaves or infected roots, should be avoided by use of Best Management Practices (BMPs). Weed control is always included as a BMP; this is another reason that elimination of weeds would be a good idea.

\section{Acknowledgments}

Thanks to John G. Phillips of the North Atlantic Area Agricultural Research Service for help with statistics and to Andrew Senesac and Irene TsontakisBradley of the Cornell University Cooperative Extension Weed Science program for weed seeds. The U.S. Department of Agriculture (USDA) prohibits discrimination in all its programs and activities on the basis of race, color, national origin, age, disability, and where applicable, sex, marital status, familial status, parental status, religion, sexual orientation, genetic information, political beliefs, reprisal, or because all or part of an individual's income is derived from any public assistance program. USDA is an equal opportunity provider and employer.

\section{Literature Cited}

1. Animal and Plant Health Inspection Service. 2007. 7 CFR Part 301. Federal Register Vol. 72, No. 38.

2. Armstrong, G. M., and Armstrong, J. K. 1948. Non-susceptible hosts as carriers of wilt Fusaria. Phytopathology 38:808-826.

3. Bendixen, L. E., Kim, K. U., Kozak, C. M., and Horn, D. J. 1981. An annotated bibliography of weeds as reservoirs for organisms affecting crops. 2. Arthropods. Research Bulletin, Ohio Agricultural Research and Development Center.

4. Bendixen, L. E., Reynolds, D. A., and Riedel, R. M. 1979. An annotated bibliography of weeds as reservoirs for organisms affecting crops. 1. Nematodes. Research Bulletin, Ohio Agricultural Research and Development Center.

5. Bogatzevska, N., and Nikolova, V. 2003. Resident weed hosts of bacterial speck and spot diseases in tomato fields and herbicides for their control. Herbologia 4:107-114.

6. Boydston, R. A., Mojtahedi, H., Crosslin, J. M., Brown, C. R., and Anderson, T. 2008. Effect of hairy nightshade (Solanum sarrachoides) presence on potato nematodes, diseases, and insect pests. Weed Sci. 56:151-154.

7. Brown, F. H., and Wiles, A. B. 1970. Reaction of certain cultivars and weeds to a pathogenic isolate of Verticillium alboatrum from cotton. Plant Dis. 54:508-512.

8. Caron, M., Fortin, J. A., and Richard, C. 1985. Influence of substrate on the interaction of Glomus intraradices and Fusarium oxysporum f. sp. radicis- lycopersici on tomatoes. Plant Soil 87:233-239.

9. Dart, N. L., and Chastagner, G. A. 2007. High recovery rate of Phytophthora from containerized nursery stock pots at a retail nursery highlights potential for spreading exotic oomycetes. Online. Plant Health Progress doi:10.1094/PHP-2007-0816-01-BR.

10. Davidson, J. M., Werres, S., Garbelotto, M., Hansen, E. M., and Rizzo, D. M. 2003. Sudden oak death and associated diseases caused by Phytophthora ramorum. Online. Plant Health Progress doi:10.1094/PHP-20030707-01-DG.

11. Ducharme, D. T., and Jeffers, S. N. 1998. Incidence of Phytophthora species in containerized woody ornamental crop nurseries. (Abstr.) Phytopathology 88:S23.

12. Erwin, D. C., and Ribeiro, O. K. 1996. Phytophthora Diseases Worldwide. American Phytopathological Society, St. Paul, MN.

13. Fichtner, E. J., Lynch, S. C., and Rizzo, D. M. 2007. Detection, distribution, survival, and sporulation of Phytophthora ramorum in a California redwood-tanoak forest soil. Phytopathology 97:1366-1375.

14. French-Monar, R. D., Jones, J. B., and Roberts, P. D. 2006. Characterization of Phytophthora capsici associated with roots of weeds on Florida vegetable farms. Plant Dis. 90:345-350.

15. Grünwald, N. J., Goss, E. M., Ivors, K., Garbelotto, M., Martin, F. N., Prospero, S., Hansen, E., Bonants, P. J. M., Hamelin, R. C., Chastagner, G., Werres, S., Rizzo, D. M., Abad, G., Beales, P., Bilodeau, G. J., Blomquist, C. L., Brasier, C., Brière, S. C., Chandelier, A., Davidson, J. M., Denman, S., Elliott, M., Frankel, S. J., Goheen, E. M., de Gruyter, H., Heungens, K., James, D., Kanaskie, A., McWilliams, M. G., Man in't Veld, W., Moralejo, E., Osterbauer, N. K., Palm, M. E., Parke, J. L., Perez Sierra, A. M., Shamoun, S. F., Shishkoff, N., Tooley, P. W., Vettraino, A. M., Webber, J., and Widmer, T. L. 2009. Standardizing the nomenclature for clonal lineages of the sudden oak death pathogen, Phytophthora ramorum. Phytopathology 99:792-795.

16. Kroon, L. P. N. M., Verstappen, E. C. P., Kox, L. F. F., Flier, W. G., and Bonants, P. J. M. 2004. A rapid diagnostic test to distinguish between American and European populations of Phytophthora ramorum. Phytopathology 94:613-620.

17. McGovern, R. J., Polston, J. E., and Mullahey, J. J. 1994. Solanum viarum: Weed reservoir of plant viruses in Florida. Intl. J. Pest Manage. 40:270-273.

18. Mitchell, D. J., Kannwischer-Mitchell, M. E., and Zentmyer, G. A. 1986. Isolating, identifying, and producing inoculum of Phytophthora spp. Pages 63-66 in: Methods for Evaluating Pesticides for Control of Plant Pathogens. K. D. Hickey, ed. American Phytopathological Society, St. Paul, MN.

19. Neal, J. C., and Derr, J. F. 2005. Weeds of container nurseries in the United States. NC Nurserymen's Assoc.

20. Ogundana, S. K. 1980. Studies on Pythium wet rot of cowpea (Vigna sinensis) in Nigeria. Afr. J. Plant Prot. 2:71-81.

21. Parke, J. L., Bienapfl, E. Oh., Rizzo, D., Hansen, E., Buckles, G., Lee, C., and Valachovic, Y. 2006. Natural infection of tanoak seedling roots by Phytophthora ramorum. (Abstr.) Phytopathology 96:S90.

22. Parke, J. L., and Lewis, C. 2007. Root and stem infection of rhododendron from potting medium infested with Phytophthora ramorum. Plant Dis. 91:1265-1270.

23. Petrie, G. A., Seguin-Swartz, G., and Gugel, R. K. 1995. Latent infection of Brassicaceae in the field by Leptosphaeria maculans (blackleg). Can. J. Plant Pathol. 17:75-81.

24. Phillips, A. J. L. 1992. Some common weed species as alternate hosts for Sclerotinia sclerotiorum. Phytophylactica 24:207-210.

25. Plenchette, C., Furlan, V., and Fortin, J. A. 1982. Effects of different endomycorrhizal fungi on five hosts grown on calcined montmorillonite clay. J. Am. Soc. Hortic. Sci. 107:535-538. 
26. Ploetz, R. C., and Haynes, J. L. 2001. How does Phytophthora capsici survive in squash fields in Southeastern Florida during the off-season? Proc. Fl. St. Hortic. Soc. 113:211-215.

27. Shishkoff, N. 2006. Susceptibility of camellia to Phytophthora ramorum, the "sudden oak death" organism. Online. Plant Health Progress. doi:10.1094/PHP-2006-03S-01-RS

28. Shishkoff, N. 2007. Persistence of Phytophthora ramorum in soil mix and roots of nursery ornamentals. Plant Dis. 91:1245-1249.

29. Shishkoff, N. 2007. Susceptibility of some Lilac cultivars and other members of the Oleaceae to Phytophthora ramorum. Plant Health Progress doi:10.1094/PHP-2007-1101-02-RS.

30. Shishkoff, N. 2009. Propagule production by Phytophthora ramorum on lilac (Syringa vulgaris) leaf tissue left on the surface of potting mix in nursery pots. Plant Dis. 93:475-480.

31. Shishkoff, N. 2009. Evaluating ornamentals as physical barriers between blocks of plants susceptible to Phytophthora ramorum, 2007-8. Plant Disease Management Reports 3. In press.

32. Shishkoff, N. 2009. A test system to quantify inoculum in runoff from Phytophthora ramorum-infected plant roots. Sudden Oak Death Sci. Sympos., 4th. Santa Cruz, CA, USA. Page 23.

33. Shishkoff, N., and Campbell, R. N. 1990. Survival of Pyrenochaeta lycopersici and the influence of temperature and cultivar resistance on the development of corky root of tomato. Plant Dis. 74:889-894.

34. Timmer, L. W., Sandler, H. A., Graham, J. H., and Zitko, S. E. 1988. Sampling citrus orchards in Florida to estimate populations of Phytophthora parasitica. Phytopathology 78:940-944.
35. Tjosvold, S. A., Chambers, D. L., Fichtner, E. J., Koike, S. T., and Mori, S. R. 2009. Disease risk of potting media infested with Phytophthora ramorum under nursery conditions. Plant Dis. 93:371-376.

36. Tooley, P. W., Kyde, K. L., and Englander, L. 2004. Susceptibility of selected ericaceous ornamental host species to Phytophthora ramorum. Plant Dis. 88:993-999.

37. Townshend, J. L., and Davidson, T. R. 1962. Some weed hosts of the northern root-knot nematode, Meloidogyne hapla Chitwood, 1949, in Ontario. Can. J. Bot. 40:543-548.

38. Tubajika, K. M., Bulluck, R., Shiel, P. J., Scott, S. E., and Sawyer, A. J. 2006. The occurrence of Phytophthora ramorum in nursery stock in California, Oregon, and Washington states. Online. Plant Health Progress doi:10.1094/PHP-2006-0315-02-RS.

39. Vieira, B. S., and Barreto, R. W. 2006. First record of Bremia lactucae infecting Sonchus oleraceus and Sonchus asper in Brazil and its infectivity to lettuce. J. Phytopathol. 154:84-87.

40. Werres, S., Marwitz, R., Man In't Veld, W., De Cock, A. W. A. M., Bonants, P. J. M., De Weerdt, M., Themann, K., Ilieva, E., and Baayen, R. P. 2001. Phytophthora ramorum sp. nov., a new pathogen on Rhododendron and Viburnum. Mycol. Res. 105(10):1155-1165.

41. Winder, R. S. 2001. Chamerion angustifolia (L.) Holub, fireweed (onagraceae). Pages 314-318 in: Biological Control Programmes in Canada 1981-2000. P. G. Mason and J. T. Huber, eds. CABI Publishing, Wallingford, UK.

42. Yadav, V. K., and Thrimurty, V. S. 2006. Weeds as alternate host for Sarocladium oryzae. Ann. Plant Prot. Sci. 14:514-515. 